\title{
Situation of Biofungicides Reconnaissance, a Case of Anthracnose Disease of Cowpea
}

\author{
Vitus Ikechukwu Obi*, Juan Jose Barriuso-Vargas \\ Department of Agricultural Science and Natural environment, University of Zaragoza, Zaragoza, Spain \\ Email: $\underline{\text { Vitemma@live.com }}$
}

Received 8 January 2014; revised 6 March 2014; accepted 21 March 2014

Copyright (C) 2014 by authors and Scientific Research Publishing Inc.

This work is licensed under the Creative Commons Attribution International License (CC BY). http://creativecommons.org/licenses/by/4.0/

(c) (i) Open Access

\begin{abstract}
Plant extracts have long been used in commercial agriculture as anti-microbial tools in food safety applications. These offer growers and agrobiologists many unique benefits which include their eco-friendliness. This work reviews the situation of Biofungicides reconnaissance in reference to fungal disease of cowpea. Twenty different pathogens were associated with various fungal diseases of cowpea and, only the species of Colletotrichum was found to have the virulence and propensity of afflicting a $\mathbf{1 0 0 \%}$ infection on a single susceptible cowpea crop. Plant families under the affliction of Colletotrichum were analyzed. The different forms of botanicals so far availed for use as potential biofungicidal were identified. Eighteen plant families were found to represent the entire plants and plant materials agrobiologically screened within a range of thirteen years and found to habour large spectra of species containing substances of biofungicidal potentials. Current position in the use of Botanicals to combat agricultural pests and disease is $7 \%$ of the total cowpea disease management options.
\end{abstract}

\section{Keywords}

Anthracnose; Biofungicides; Biopesticides; Colletotrichum destructivum; Cowpea.

\section{Introduction}

Cowpea (Vigna unguiculata (L.) Walp) is a leguminous, annual grain crop in the bean family (Fabaceae/Leguminosae), with high degree of variation in growth habit, leaf shape, flower colour and seed size and colour, cultivated mostly in the humid tropics of the globe for its seeds, as a vegetable crop, green manure, fodder, as a cash crop and or cover crop [1]-[4]. The crop’s haulms are also valuable source of livestock protein [5].

Cowpea is a native to Africa where they are often intercropped with maize (Zea mays L.), Sorghum (Sorghum

\footnotetext{
*Corresponding author.
} 
bicolor (L.) Moench), Pearl millet (Pennisetum americanum (L.) Leeke) and Cassava (Manihot esculenta Crantz) [6] [7]. This all important global crop, encounters a number of operational constraints, including pests and diseases that limit its production and yield potentials from seedling to harvest [3] [4] [7] and often provoking grain yield loss of over $35 \%$ [8] [9].

Major pathogenic groups associated with cowpea diseases, include: fungi, bacteria, viruses, nematodes and the parasitic flowering plants [3]. And Anthracnose is its major disease, causing severe damage and loses under low temperature, high humidity and free moisture [3] [6]. Though the major fungal pathogen of Cowpea crop is the Colletotrichum destructivum O'Gara, there are some other old and new fungal pathogens that influence its existence, reproduction and survival. Some of these pathogens attack and infect the roots of the crop [10]; stems [11] [12]; leaves [3] [13] [14]; pods and fruits [15] [16]; seeds/seedlings [17] [18]; whole plant parts [4].

C. destructivum is polycyclic, having multiple life cycles in a growing season [19], and hemibiotrophic, thriving in both living and dead tissues [4]. The pathogen is seed borne fungus [20] [21], and can survive for at least two years on diseased stem tissues, plant debris, either on the soil surface or beneath [4].

The $C$. destructivum sporulates readily on infected cowpea at localized infection foci to produce anthracnose symptom within 96hrs of inoculation [22], in the form of lesions as small angular brown spots on the leaf petiole, the lower surface of leaves and leaf veins of cowpea grown under different cropping patterns [6]. These various spots created later coalesced to produce a brick red to brown discoloration of the entire leaf. Symptoms are usually delayed (delitescent infection) until production of flowering buds. This degree of virulence on cowpea often leads to product yield loss between $35 \%$ and 50\% [8] [9].

Available management techniques for Anthracnose disease of cowpea include the use of Biocontrol systems (bioagents), pesticides (conventional/synthetic chemicals), cultural observations (clean seeds/hygienic fields and practices), HPR (host plant resistance) and botanicals (Biopesticides/no synthetic chemicals) [23]. Some, though seem effective, are enlaced with residual and often negative and indelible impressions [24].

The global quest for "back to nature" continues to augment the need and desirability to search for the alternative which employs natural agro-biological balance (Biopesticides) to address plant disease issues. This is remotely aimed at protecting the soil that supports the life of these crops among other horticultural plants [25], and in extension safeguards the environment for every other vivo organism.

The Environmental Protection Agency (EPA-USA) defines a Biopesticides as a pesticide derived from natural materials such as animals, plants, bacteria and certain minerals [26]. Biopesticides of plant origin are the botanicals (Figure 1). Biological control of plant disease through the use of antagonistic micro organism [4] [27]-[29] and botanical control of plant disease through the use of plant extracts [7]-[9] are two major ways in the control of plant disease in respect to natural agro biological balance.

In the evaluation of some botanicals against $C$. destructivum, Akinbode and Ikotun [4] inhibited the growth of the pathogen in vitro using Nicotiana tabacum plant extract. Crude botanical extracts from stem back and root bark of Azadiractha indica, Vernonia amygdalina and Cochlospermum planchonii exhibited strong fungi toxicity against Colletotrichum capsici as reported by Nduagu et al. [25].

Palhano et al. [30] inactivated spores of Colletotrichum gloeosporiodes using high hydrostatic pressure separate and combined with Citral or lemongrass (Cymbopogon citratus) essential oil. Their work reiterated the need for the use of plant essential oils as an alternative for crop health problems considering the safety and stability of the soil and its environment.

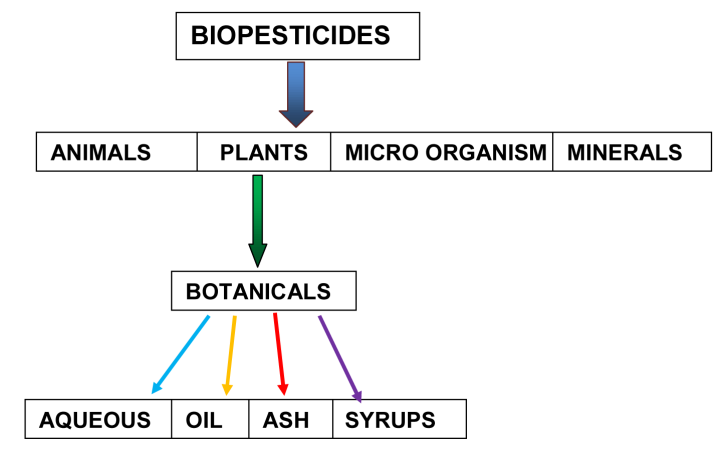

Figure 1. Botanicals in Biopesticides. 
The search for bioactive substances from the plant world has led researches to distinctive regions of plants. Flowers, leaves, barks, seeds, fruits, roots and at times whole plant could be employed in the search for botanicals [31]. The seeds of neem, Azadiractha indica A. Juss and fruits of bush pepper, Xylopia aethiopica (Dunal) A. Rich were used in the work of Amadioha and Obi [8], while in another similar study the same authors employed the leaves of scent plant, Ocimum gratissimum (L.) and lemon grass, Cymbopogon citratus D. C. Stapf., for anthracnose disease of cowpea [32]. Amadioha [9] used the leaves of Piper nigrum, Ocimum sanctum and Citrus limon in his study against $C$. lindemuthianum.

Akinbode \& Ikotun [4] and Colpas et al. [23] utilized the leaves of Nicotiana tabacum and Ricinus communis, and Ocimum gratissimum respectively in the scientific investigation for bioagents/botanicals in control of $C$. destructivum. Nduagu et al. [25] screened eleven plants on growth of Colletotrichum capsici (Synd) Butler \& Bisby concentrating on leaves, stem bark and root barks of the concerned plants.

Different methods and techniques have been employed by scientists in the extraction and characterization of products from plants. A plant material could thus be harnessed in its fresh, or air/sun/oven-dried form, and with an adoption of extraction methods such as the use of hot or cold water for aqueous botanicals [4] [23] [25] [32] [33]; organic solvents for oil botanicals [8]; crude ashes for crude powder botanicals [34] [35]

There are weighty merits for the quest for wider exploration of Biopesticides in the field of agriculture. Biopesticides tend to pose fewer risks than conventional pesticides; Biopesticides are usually inherently less toxic than conventional pesticides; when used as a component of integrated pest management (IPM) programmes [25]. Biopesticides can greatly decrease the use of conventional pesticides, while crop yields remain high; Biopesticides require much less data and time frame to register than a conventional pesticide [36]. They are non residue producing control agent, making them eco-friendly and easy to use class of Reduced-risk Fungicides. It is in the support of all these that the European Community, like in other developed parts of the world, established a European Commission Working Document (SANCO/10472rev.5). This specifies data requirements for active substances of plants protection products made from plants or plant extracts.

\section{Discussion}

The global comparison of scientific research and publications, on protection of Vigna unguiculata (L.) (Table 1), projected the Asian region with the highest of $35.9 \%$. This was followed by Africa with $24.80 \%$. The least scientific research and publications on protection of cowpea was from Australia with $1.40 \%$.Scientific documents on cowpea diseases according to pathogen groups, for five years range indicated the fungi to be on top with 35.6\% (Table 2).This relatively high level percentage of scientific papers points at the major pathogenic constrains and its economic importance in the cultivation of cowpea crops. Regrettably the Biopesticides (Botanicals) which is a protective drive for a natural agro-biological balance in the fight against agricultural pests and disease was associated with about $7 \%$ of the total cowpea disease management options (Figure 2), a clear indication of under exploration of this area. This corroborates with the observation in the work of Emechebe \& Lagoke [3].

It was observed that each cowpea pathogen has different regions of interest on a "whole cowpea plant". This work, therefore, considered a cowpea crop from different botanical dimensions of six parts, and it was discovered that $30 \%$ of the fungal infections occur on the foliar part of the crop, $25 \%$ on the stems, $15 \%$ on the roots, $10 \%$ on the pods/fruits, $25 \%$ on the seeds/seedlings and $10 \%$ on the whole parts of the plant (Figure 3).

There was an indication that while the other nineteen pathogenic fungal species (Table 3) poses the ability each of attacking only about a meager $20 \%$ of a cowpea crop, Colletotrichum species especially the C. destructivum \& C. truncatum, have in stock $100 \%$ virulence on a single crop each at a given pathogenic situation (Table 3). This corroborates with the findings of Latunde-Dada et al. [22], Latunde-Dada \& Lucas [37], and Akinbode \& Ikotun [4].

There are eighteen plant families presently under the anguish of the Colletotrichum Corda (Table 4). About 28\% family interaction existed between plant families under the affliction of Colletotrichum and the plant families screened for antifungal properties (Table 6) as derived from Table 4 \& Table 5. These apparitions were observed within the five plant families of Asteraceae, Caricaceae, Fabaceae, Lauraceae and Poaceae. The rest of about $72 \%$ were unique in occurrence, hence no family interactions among them (Table 6.) The extrapolated values appear to affirm the indication on table 5 of this work that of all the entire plant families in existence only about eighteen (18) has been screened for their biofungicides characteristics between 1998 and 2011. 
Table 1. Relative contributions, geographically, of scientific publication on cowpea diseases.

\begin{tabular}{ccc}
\hline Geographical area. & Number of papers. & Percentage of papers contributed (\%). \\
\hline Africa & 85 & 24.80 \\
Asia & 123 & 35.90 \\
Australia & 5 & 1.40 \\
Europe & 28 & 8.20 \\
North America & 75 & 21.80 \\
S. America \& the Caribbean & 27 & 7.90 \\
\hline
\end{tabular}

Source: [3].

Table 2. Publications, for five years, on cowpea diseases according to pathogen groups.

\begin{tabular}{ccc}
\hline Group of pathogen & Number of papers & Percentage of papers (\%) \\
\hline Bacteria & 21 & 6.10 \\
Fungi & 122 & 35.6 \\
Nematodes & 69 & 20.10 \\
Parasitic plants & 19 & 5.50 \\
Viruses & 112 & 32.7 \\
\hline
\end{tabular}

Source: [3].

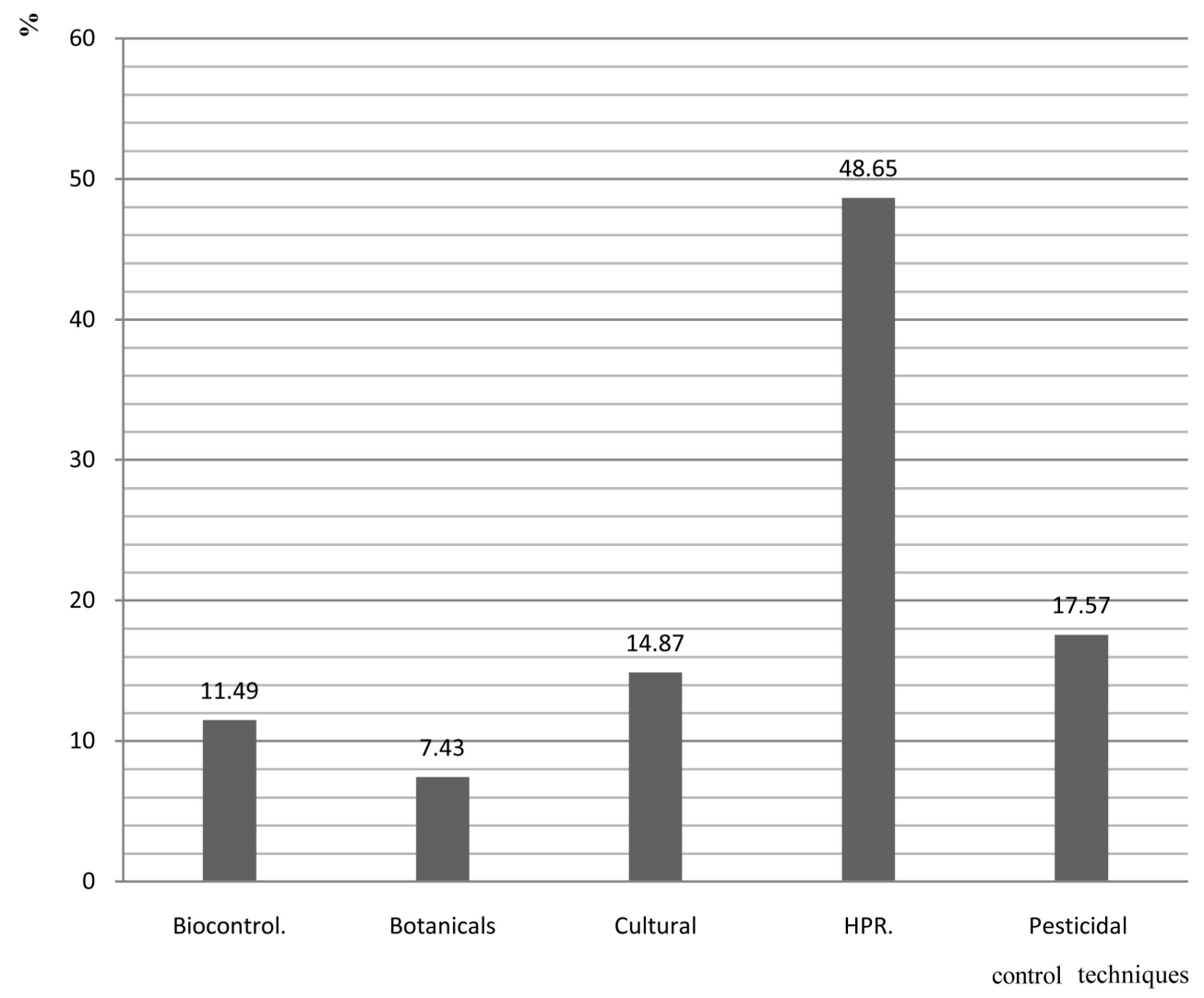

Figure 2. Percentage disease control techniques on Vigna unguiculata for a media decade.

The products screened during this thirteen years span were of various forms or state, such as (1) Aqueous: botanicals extracted using water as the solvent. The water also forms the extract solution [4] [25]; 2) Syrup: botanicals of a higher measure of viscosity having been extracted with a solvent other than water, and also containing some of the extracting liquid in its solution [23] [38]; 3) Oil: botanicals in the form of essential oil of the 


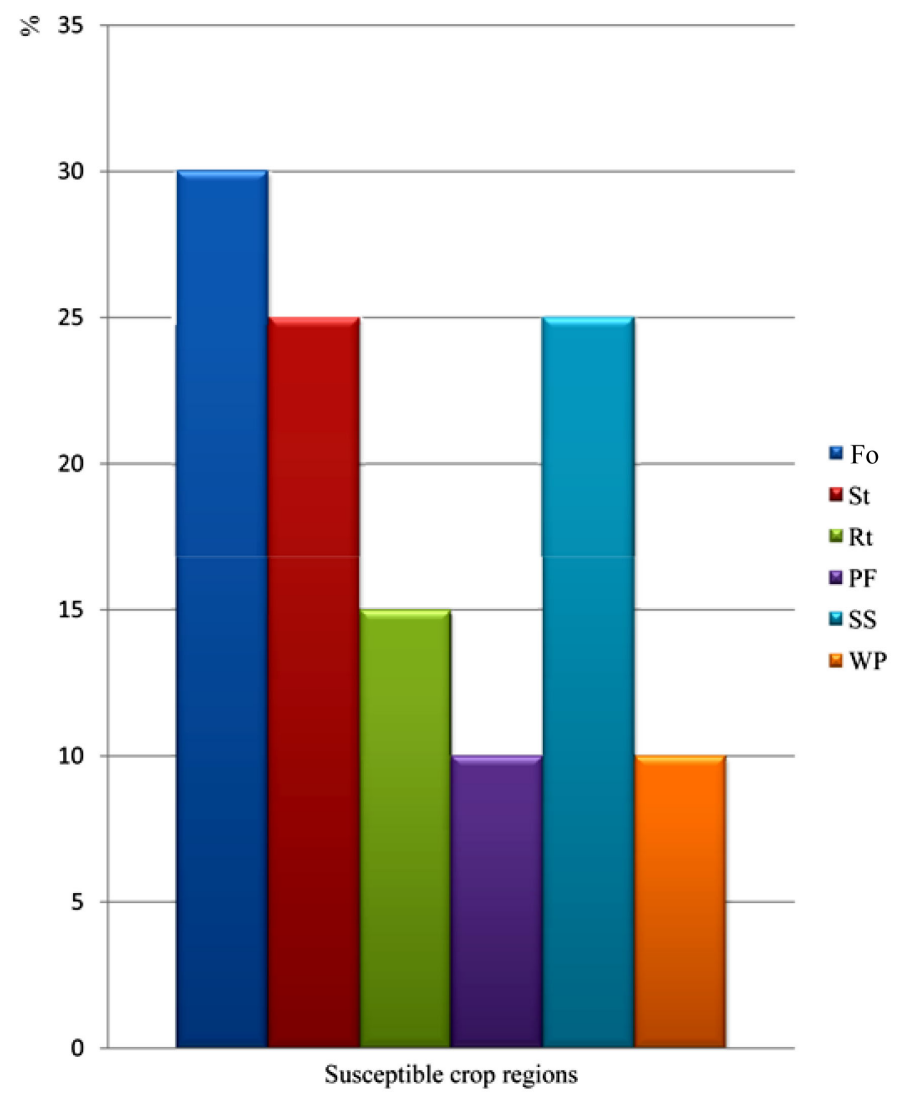

Figure 3. Percentage regional fungal attack on Vigna unguiculata crop. (Fo = foliar; St = stem; Rt = root; PF = pod/fruit; SS = seed $/$ seedlings; $\mathrm{WP}=$ whole plant).

test plants, usually extracted through a condensation system [8]; and 4) Ash: botanicals produced in the form of residues powder left after the combustion of a test plant material [34] [35].

Nevertheless, the botanical forms enumerated in this study could be extended to produce additional form by the application of further processing treatment on the original form. For example the Syrup produced in the work of Win et al. [38] was utilized in its dry crude botanical extract state after subjecting the initial extract syrup to an evapoconcentration system. This study, however, observed that most of the botanicals screened for this span of thirteen years (1998 to 2011) were produced and also utilized in their aqueous form. And considering the total 33 frequency occurrence of botanical forms (Table 5), the aqueous botanicals was $51.52 \%$, followed by the syrup (15.15\%), ash (18.18\%) and the oil form of $15.15 \%$. The relative easy and economy of production could be responsible for the high percentage value obtained with aqueous botanical evaluation.

\section{Conclusions}

Anthracnose disease remains a devastating health problem to cowpea crop and an equated hindrance to its economic cultivation. The major afflicting pathogen Colletotrichum destructivum O'Gara has the virulence of one hundred percent (100\%) infection on a single crop stand (that is every part of the crop is subject to attack and infection by $C$. destructivum at a given pathogenic situation).

The use of botanicals remains suitable contest to adequate disease management options, at least for its characteristics ease of production, economy and ecological amiability.

This study has availed the fact that with the high global yearning for the urgent replacement of conventional (chemical) fungicides in disease management with the ecologically compatible bio-fungicides, the seemingly several works in this direction is merely about $7 \%$ of the different management systems as indicated on cowpea disease control options and therefore, advocates for more reconnaissance in this essential area of agro-biological 
Table 3. Colletotrichum Corda and other fungal pathogens of Vigna unguiculata.

\begin{tabular}{|c|c|c|c|}
\hline Pathogen & Disease afflicted & Region affected & Reference \\
\hline Alteneria cassiae Juria \& Khan & Alternaria leaf spot & Foliar & [39] \\
\hline Cercospora canescens Ellis \& Martin & Cercospora leaf spots & Foliar & [13] \\
\hline Choanephora cucurbitarum (Berk \& Rav.) & Choanephora pod rot & Pods/fruits & [15] \\
\hline Colletotrichum dematium (Pers. ex Fr.) & $\begin{array}{l}\text { Colletotrichum } \\
\text { stem disease }\end{array}$ & Stem & [12] \\
\hline Colletotrichum destructivum O’Gara & Anthracnose & Every part & [4] \\
\hline $\begin{array}{l}\text { Colletotrichum capsici (Syd.) Butl. \& Bisb. } \\
\quad(=\text { Colletotrichum truncatum (Schw.) }\end{array}$ & Brown blotch & All parts & [22] [37] \\
\hline Fusarium oxysporum f.sp tracheiphilum & Fusarium wilt & Seedlings & [17] \\
\hline Fusarium oxysporum f. sp vasinfectum (E. F. Smith) Synd \& Hans & Fusarium wilt & Seedlings & [40] \\
\hline Macrophomina phaseolina & Macrophomina blight & $\begin{array}{c}\text { Seedlings } \\
\text { (severe mortality) }\end{array}$ & [41] \\
\hline $\begin{array}{l}\text { Mycospharella cruenta Latham. } \\
\text { (Anormoph of Pseudocercospora) }\end{array}$ & Pseudocercospra leaf spots & foliar & [3] \\
\hline Phomopsis longicola & Phomopsis pod spot & Pods/fruits & {$[16]$} \\
\hline $\begin{array}{l}\text { Protomycopsis phaseoli Ramak \& Subram. } \\
\text { (=Entyloma vinae Batista) }\end{array}$ & Leaf smut & Foliar & [14] \\
\hline Pythium aphanidermatum (Edison) Fitz & Pythium soft rot & Stem & [11] \\
\hline Pythium ultimum & Damping off (pre/post) & Seed/seedling & [18] \\
\hline Phytophthora cactorum (Leb. \& Chon.) Schroet. & Red stem canker & Stem/root & [10] \\
\hline Phytophthora vignae Puress. & Phytophtora stem rot & Stem/root & [10] \\
\hline Sphaceloma sp.(Anamorph of Elsinoe phaseoli Jenkin) & Sphaceloma scab. & Hypocotyls \& epicotyls & [3] \\
\hline Sclerotiumrolfsii Sacc. (Teliomorph: Corticum rolfsii Curzi). & Basal stem rot/wilt & Stem & [42] \\
\hline Uromyces appendiculatus (pers.) Unger (=U. vinae Barclay). & Brown rust & Foliar & [43] \\
\hline Thanatephorus cumeris (Frank) Donk (=Rhizoctonia solani Kuhn) & $\begin{array}{l}\text { Web blight Rot (root rot } \\
\text { /seedling disease complex) }\end{array}$ & Root/seedling & [3] \\
\hline
\end{tabular}

Table 4. Plant families under the affliction of Colletotrichum Corda (1995-2011).

\begin{tabular}{|c|c|}
\hline Family & Reference. \\
\hline Amaranthaceae Juss. & {$[44]$} \\
\hline Anacardiaceae Lindl. & {$[45]$} \\
\hline Asteracea Bercht. \& J. Presl. & {$[27][44]$} \\
\hline Brassicaceae Juss. & {$[46]$} \\
\hline Carcaceae Dumort. & {$[30]$} \\
\hline Convovulaceae Juss. & {$[27]$} \\
\hline Cucurbitaceae Juss. & [44] \\
\hline Cuscutaceae Dum. (=Convovulaceae) & {$[27]$} \\
\hline Fabaceae Lindl. & {$[3][8][22][44][47]$} \\
\hline Lauraceae Juss & {$[45]$} \\
\hline Leguminosae Juss., Non. Con (=Fabaceae Lindl.) & {$[1][3][6][9]$} \\
\hline Linaceae. $\mathrm{L}$ & {$[37]$} \\
\hline Malvaceae Juss & {$[44]$} \\
\hline Musaceae Juss & {$[44]$} \\
\hline Oleaceae Hoffmgg.\& Link & {$[48][49]$} \\
\hline Poaceae Barnhart (=GramineaeJuss, Non. Con.) & {$[27][50]$} \\
\hline Roasaceae Adans & {$[44][48][51]$} \\
\hline Rubiaceae Linn & {$[52][53]$} \\
\hline
\end{tabular}


Table 5. Plant families screened for biofungicidal properties (1998-2011).

\begin{tabular}{|c|c|c|c|c|}
\hline Family & Samples & Bioassay & Botanical Form & Reference \\
\hline Alliaceae & Garlic spp & In vitro & Syrup & [38] \\
\hline Annonaceae & Xylopia aethiopica; Annona reticulata & In vitro/In vivo & Oil extract; Aqueous. & [8] [54] \\
\hline Arecaceae & Elaeis guineensis; Cocos nucifera & In vitro; In vitro & Ashes; Ashes & [34] [35] \\
\hline Asteraceas & Chromoleana odorata; Vernonia amygdalina & In vitro; In vivo & Aqueous; Aqueous. & [25] [33] \\
\hline Caricaceae & Carica papaya & In vivo & Aqueous. & [33] \\
\hline Cochlospermaceae & Cochlospermum planchonii & In vitro & Aqueous. & [25] \\
\hline Euphorbiaceae & $\begin{array}{l}\text { Ricinus comunis; Hymenocardia acida; } \\
\text { Euphorbia prostrata }\end{array}$ & In vitro; In vitro; In vitro & Aqueous; Aqueous; Ashes & [4] [25] [35] \\
\hline Fabaceae & Tephrosia vogelii; Senna alata & In vitro; In vitro & Aqueous; Ashes & [2] [35] \\
\hline Lamiaceae & $\begin{array}{c}\text { Thymus vulgaris; Ocimum gratissimum; } \\
\text { O. sanctum }\end{array}$ & In vivo; In vivo; In vitro & $\begin{array}{l}\text { Oil extract; Aqueous; } \\
\text { Aqueous/Syrup }\end{array}$ & $\begin{array}{l}{[23][25][32]} \\
{[55]}\end{array}$ \\
\hline Lauraceae & Cinnamon zeylanicum & In vivo; In vitro & Oil extract ;Syrup & [38] [55] \\
\hline Meliciaceae & Azadiractha indica & In vitro/In vivo. & Oil extract; Aqueous & [8] [25] \\
\hline Myrtacea & Psidium guajava. & In vitro & Aqueous. & [25] \\
\hline Piperaceae & Piperaceae & In vitro/In vivo & Aqueous/syrup; Syrup & [9] [38] \\
\hline Plumbaginaceae & Plumbago zeylanica & In vitro & Ashes & [35] \\
\hline Poaceae & Cymbopogon citratus & In vitro/In vivo; In vitro & Aqueous; Oil extract & [30] [32] \\
\hline Potederiaceae & Eichhomia crassipes & In vitro & Ashes. & [34] \\
\hline Rutaceae & Citrus limon & In vitro & Aqueous/Syrup; Aqueous. & [9] [25] \\
\hline Solanaceae & Nicotiana tabacum & In vitro & Aqueous. & [4] \\
\hline
\end{tabular}

Table 6. Spatial interaction between screened and pathogen afflicted plant families.

\begin{tabular}{|c|c|c|c|}
\hline $\begin{array}{l}\text { Plant family screened for } \\
\text { biofungicidal properties(A) }\end{array}$ & $\begin{array}{l}\text { Plant family under the } \\
\text { affliction of Colletotrichum(B) }\end{array}$ & $\begin{array}{c}\text { Existence of spacial family } \\
\text { interaction between A \& B = C }\end{array}$ & $\begin{array}{c}\text { Percentage family interaction } \\
\text { [C/(AorB }) \times 100]\end{array}$ \\
\hline Alliaceae & Amaranthaceae Juss. & & \\
\hline Annonacea & Anacardiaceae Lindl. & & \\
\hline Arecaceae & Asteracea Bercht. \& J. Presl. & & \\
\hline Asteracea Bercht. \& J.Presl. & Brassicaceae Juss. & Asteracea Bercht. \& J. Presl. & \\
\hline Caricaceae Dumort. & Caricaceae Dumort. & Caricaceae Dumort & \\
\hline Cochlospermaceae & Convovulaceae Juss. & & \\
\hline Euphorbiaceae & Cucurbitaceae Juss. & & \\
\hline Fabaceae Lindl. & Cuscutaceae Dum. (=Convovulaceae) & Fabaceae Lindl. & \\
\hline Lamiaceae & Fabaceae Lindl. & & \\
\hline Lauraceae Juss & Lauraceae Juss & Lauraceae Juss. & $27.78 \%$ \\
\hline Meliciaceae & $\begin{array}{l}\text { Leguminosae Juss., Non. Con } \\
\text { (=Fabaceae Lindl.) }\end{array}$ & & \\
\hline Myrtaceae & Linaceae L. & & \\
\hline Piperaceae & Malvaceae Juss & & \\
\hline Plumbaginaceae & Musaceae Juss & & \\
\hline Poaceae Barnhart & Oleaceae Hoffmgg. \& Link & Poaceae Barnhart & \\
\hline Potederiaceae & $\begin{array}{c}\text { Poaceae Barnhart } \\
\text { (=Gramineae Juss, Non. Con.) }\end{array}$ & & \\
\hline Rutaceae & Roasaceae Adans & & \\
\hline Solanaceae & Rubiaceae Linn & & \\
\hline
\end{tabular}

\footnotetext{
${ }^{1}$ Nominal value of $\mathrm{A}$ or $\mathrm{B}$ equals to 18 ; Nominal value of $\mathrm{C}$ is equals to 5 .
} 
system whose endpoint includes the provision of an eco-friendly global environment.

\section{References}

[1] Latunde-Dada, A.O., O’Connell, R.J., Nasa, C., Pring, R.J., Lucas, J.A. and Bailey, J.A. (1996) Infection Process and Identity of the Hemibiotrophic Anthracnose Fungus Colletotrichum destructivum from cowpea (Vigna unguiculata). Mycological Research, 100, 1133-1141. http://dx.doi.org/10.1016/S0953-7562(96)80226-7

[2] Allen, D.J., Thottappilly, G., Emechebe, A.M. and Singh, B.B. (1998) Disease of Cowpea. In: Allen, D.J. and Lenne J.M., Eds., Pathology of Food and Pasture Legumes, CAB International, Wallingford, 267-324.

[3] Emechebe, A.M. and Lagoke, S.T.O. (2002) Recent Advances in Research on Cowpea Diseases in Challenges and Opportunities for Enhancing Sustainable Cowpea Production. Proceeding of the World Cowpea Conference III, the International Institute of Tropical Agriculture (IITA), Ibadan, 4-8 September 2000, 94-123.

[4] Akinbode, O.A. and Ikotun, T. (2008) Evaluation of Some Bioagents and Botanicals in In Vitro Control of Colletotrichum destructivum. African Journal of Biotechnology, 7, 868-872.

[5] Owolade, O.F., Adediran, J.A., Akande, M.A. and Alabi, B.S. (2006) Effect of Application of Phosphorus Fertilizer on Brown Blotch Disease of Cowpea. African Journal of Biotechnology, 5, 343-347.

[6] Adebitan, S.A. and Ikotun, T. (1996) Effect of Plant Spacing and Cropping Pattern on Anthracnose Colletotrichum lindemuthianum of Cowpea. Fitopatología Brasileira, 21, 5-12.

[7] Adebanjo, A. and Bankole, S.A. (2004) Evaluation of Some Fungi and Bacteria for Control of Anthracnose Disease of Cowpea. Journal of Basic Microbiology, 44, 3-9. http://dx.doi.org/10.1002/jobm.200310310

[8] Amadioha, A.C. and Obi, V.I. (1998) Fungitoxic Activities of Extracts from Azadiractha indica and Xylopia aethiopica on Colletotrichum lindemuthianum in Cowpea. Journal of Herbs, Spices, and Medicinal Plants, 6, 33-40. http://dx.doi.org/10.1300/J044v06n02_04

[9] Amadioha, A.C. (2003) Evaluation of some plant leaf extracts against Colletotrichum lindemuthianum in cowpea. Acta Phytopathologica et Entomologica Hungarica, 38, 259-265.

[10] Fernando, W.G.D. and Linderman, R.G. (1997) The Effect of Mycorrhizal (Glomus intraradisces) Colonization on the Development of Root and Stem Rot (Phytophthora vignae) of Cowpea. Journal of the Natural Sciences, 25, 39-47.

[11] Bankole, S.A. and Adebanjo, A. (1998) Efficacy of Some Fungal and Bacteria Isolates in Controlling Wet Rot Disease of Cowpea Caused by Pythium aphanidermatum. Journal of Plant Protection, 11, 37-43.

[12] Smith, J.E., Christian, L. and Aveling, T.A.S. (1999) Infection Process of Colletotrichum dematium on Cowpea Stems. Mycological Research, 103, 230-234. http://dx.doi.org/10.1017/S0953756298006868

[13] Amadi, J.E. (1995) Chemical Control of Cercospora Leaf Spot Disease of Cowpea (Vigna unguiculata (L.) Walp.). Agrosearch, 1, 101-107.

[14] Santos, A.A., Quindere, M.A.W. and Melo, M.B. (1997) Evaluation of Cowpea Genetypes for Resistance to Cowpea Smut (Entyloma vignae). Fitopatologia Brasileira, 22, 77-78.

[15] Munoz, M.A. and Tamayo, M.P.J. (1994) The Process of Choanephora cucurbitarum in Cowpea [Vigna unguiculata (L.) Walp.]. ASCOLF Informa, 20, 4-5.

[16] Roy, K.W. and Ratnayake, S. (1997) First Report of Phomopsis lengicolla Infection of Cowpea Pods and Seeds in Mississippi. Plant Diseases, 81, 693. http://dx.doi.org/10.1094/PDIS.1997.81.6.693B

[17] Smith, S.N., Helms, D.M. and Temple, S.R. (1999) The Distribution of Fusarium Wilts of Blackeyed Cowpea within California Caused by Fusarium oxysporum f. sp tracheiphilum Race 4. Plant Diseases, 83, 694. http://dx.doi.org/10.1094/PDIS.1999.83.7.694C

[18] Aveling, T.A.S. and Adandonon, A. (2002) First Report of Pre and Post Emergence Damping-Off of Cowpea Caused by Pythium ultimum in South Africa. Plant Disease Reporter, 84, 922. http://dx.doi.org/10.1094/PDIS.2000.84.8.922B

[19] Schumann, L.G. and D`Arcy, C.J. (2006) Essential Plant Pathology. The American Phytological Society, 338.

[20] Amusa, N.A., Ikotun, T. and Osikanlu, Y.O.K. (1994) Screening Cowpea and Soybean Cultivars for Resistance to Anthracnose and Brown Blotch Diseases Using Phytotoxic Metabolites. African Crop Science Journal, 2, 221-224.

[21] Fokung, C.N., Ikotun, T. Dixon, A.G.O. and Akem, C.N. (1997) First Report of Colletotrichum gloeosporioides f. sp. Manihot, Cause of Cassava Anthracnose Disease Being Seed Born and Seed Transmitted in Cassava. Plant Disease, 81, 695. http://dx.doi.org/10.1094/PDIS.1997.81.6.695C

[22] Latunde-Dada, A.O., O’Connell, R.J., Bowwyer, P. and Lucas, J.A. (1999) Cultivar Resistance to Anthracnose Disease of Cowpea (Vigna unguiculata (L.)Walp.) Caused by Colletotrichum destructivum O'Gara. European Journal of Plant Pathology, 105, 445-451. http://dx.doi.org/10.1023/A:1008765013572 
[23] Colpas, F.T., Schwan-Estrada, K.R.F., Stangarlin, J.R., Ferrarse, M.L., Scapim, C.A. and Bonaldo, S.M. (2009) Induction of Plant Defense Responses by Ocimum gratissimum L. Leaf Extracts. Summa Phytopathologica, 35, 191-195.

[24] Jansch, S., Rombkeand, J. and Frische, T. (2009) Ecological Effects of the Accumulation of Copper in Soil. (Results of a Literature Review) Extended Abstract in Zum Gleichnamigen Vortragbeider, 4, 70.

[25] Nduagu, C., Ekefanand, E.J. and wankiti, A.O.N. (2008) Effect of Some Crude Plant Extracts on Growth of Colletotrichum capsici (Synd) Butler and Bisby, Causal Agent of Pepper Anthracnose. Journal of Applied Biosciences, 6, 184190.

[26] Polyversum (2012) http://www.polyversumla.com

[27] Amusa, N.A. and Ikotun, T. (1995) Phytotoxicity of Metabolites Produced by Some Colletotrichum Species on Weeds and Crop Plants in Nigeria. International Journal of Tropical Plant Diseases, 13, 113-119.

[28] Bankole, S.A. and Adebanjo, A. (1996) Biocontrol of Brown Botch of Cowpea Caused by Colletotrichum truncatumwith Trichoderma viride. Crop Protection, 15, 633-636. http://dx.doi.org/10.1016/0261-2194(96)00028-2

[29] Adekunle, A.T., Cardwell, K.F., Floriniand, D.A. and Ikotun, T. (2001) Seed Treatment with Trichoderma Species for Control of Damping-Off of Cowpea Caused by Macrophomina phaseolina. Biocontrol Science and Technology, 11, 449-457. http://dx.doi.org/10.1080/09583150120067481

[30] Palhano, F.L., Vilches, T.T.B., Santos, R.B., Orllando, M.T.D., Ventura, J.A. and Fernandos, P.M.B. (2004) Inactivation of Colletotrichum gloeosporiodes Spores by High Hydrostatic Pressure Combined with Citral or Lemon Grass Essential Oil. International Journal of Food Microbiology, 95, 61-66. http://dx.doi.org/10.1016/j.ijfoodmicro.2004.02.002

[31] Obi, V.I. and Onuoha, C.I. (2000) Extraction and Characterization Methods of Plants and Plant Products. In: Ogbulie, J.N. and Ojiako, O.A., Eds., Biological and Agricultural Techniques, Websmedia Publishers, Owerri, 271-286.

[32] Amadioha, A.C. and Obi, V.I. (1999) Control of Anthracnose Disease of Cowpea by Cymbopogon citratus and Ocimum gratissimum. Acta Phytopathologica et Entomologica Hungarica, 34, 85-89.

[33] Ogwulumba, S.I., Ugwuoke, K.I. and Iloba, C. (2008) Prophylactic Effect of Pawpaw Leaf and Bitter Leaf Extracts on the Incidence of Foliar Mycopathogens of Groundnut (Arachis hypogaea L.) in Ishiagu, Nigeria. African Journal of Biotechnology, 7, 2878-2880.

[34] Enikumehinand, A.O. and Kehinde, I.A. (2007) In Vitro Screening of Some Tropical Ash Samples against Seed Borne Pathogen of Wheat (Tritticum aestivum L.). Australasian Plant Pathology, 36, 587-590. http://dx.doi.org/10.1071/AP07066

[35] Obi, V.I. and Ugwunze, N.N. (2009) Control of Tuber Roots of Colocasia esculenta L. Using Plant Ash. Recent Progress in Medicinal Plants, 23, 345-355.

[36] Regulating Pesticides (2012). http://www.epa.gov/PR_Notices/pr97-3.html

[37] Latunde-Dada, A.O. and Lucas, J.A. (2007) Localized Hemibiotrophy in Colletotrichum: Cytological and Molecular Taxonomic Similarities among C. destructivum, C. linicola and C. truncatum. Plant Pathology, 56, 437-447. http://dx.doi.org/10.1111/j.1365-3059.2007.01576.x

[38] Win, N.K., Jitareerat, P., Kanlayanarat, S. and Sangchote, S. (2007) Effect of Cinnamon Extract, Chitosan Coating, Hot Water Treatment and Their Combination on Crown Rot Disease and Quality of Banana Fruit. Postharvest Biology and Technology, 45, 333-340. http://dx.doi.org/10.1016/j.postharvbio.2007.01.020

[39] Grangeand, N.L.A. and Aveling, T.A.S. (1998) First Report of Alternaria cassiae on Cowpea. Plant Disease, $82,1171$.

[40] Ushamalini, C., Rajappan, K. and Gangadharan, K. (1997) Inhibition of Macrophomina phaseolina and Fusarium oxysporum f. sp. tracheiphilum by Antagonists under in Vitro Conditions. Plant Disease Research, 12, 168-170.

[41] Ratnoo, R.S., Jain, K.L. and Bhatnagar, M.K. (1997) Effects of Atmospheric Temperature on the Development of Ashy Stem Blight of Cowpea. Journal of Mycology and Plant Pathology, 27, 90-91.

[42] Muqit, A., Haque, M.S. and Hossain, M.M. (1996) Reaction of Cowpea Lines against Sclerotiumrolfii. Bangladish Journal of Plant Pathology, 12, 63.

[43] Heath, M.C. (1998) Involvement Reactive Oxygen Species in the Response of Resistant (Hypersensitive) or Susceptible Cowpea to the Cowpea Rust Fungus. New Phytologist, 138, 251-263. http://dx.doi.org/10.1046/j.1469-8137.1998.00897.x

[44] Liu, B., Wasilwa, L.A., Morelock, T.E., O’Neil, N.R. and Correll, J.C. (2007) Comparison of Colletotrichum orbiculare and Several Allied Colletotrichum s for mtDNA RFLPs, Intron RFLP and Sequence Variation, Vegitative Compatibility, and Host Specificity. The American Phytopathological Society, 97, 1305-1314. http://dx.doi.org/10.1094/PHYTO-97-10-1305

[45] Sanders, G.M., Korstenand, L. and Wehner, F.C. (2007) Survey of Fungicides Sensitivity in Colletotrichum gloeosporiodes from Different Avocado and Mango Production Areas in South Africa. European Journal of Plant Pathology, 
106, 745-752.

[46] Sun, H. and Zhang, J.-Z. (2009) Colletotrichum destructivum from Cowpea Infecting Arabidopsis thaliana (Wall Cress) and Its Identity to C. higginsianum. European Journal of Plant Pathology, 125, 459-469. http://dx.doi.org/10.1007/s10658-009-9495-2

[47] Mould, M.J.R., Robb, J. and Boland, G.J. (1992) Loss of Resistance to Colletotrichum trifolii in In Vitro Regenerated Alfalfa. Plant Cell, Tissue and Organ Culture, 28, 207-213. http://dx.doi.org/10.1007/BF00055519

[48] Salazar, S.M., Castagnaro, A.P., Arias, M.E., Chalfoun, N., Tonelloand, U. and Diaz-Ricci, J.C. (2007) Induction of a Defense Response in Strawberry Mediated by a Virulent Strain of Colletotrichum. European Journal of Plant Pathology, 117, 109-122. http://dx.doi.org/10.1007/s10658-006-9075-7

[49] Gomes, S., Prieto, P., Martins-Lopes, P., Carvalho, T., Martin, A. and Guedes-Pinto, H. (2009) Development of Colletotrichum acutatum on Tolerant and Susceptible Olea europaea L. Cultivars: A Microscopic Analysis. Mycopathologia, 168, 203-211. http://dx.doi.org/10.1007/s11046-009-9211-y

[50] Moore, J.W., Ditmore, M. and Tebeest, D.O. (2008) Pathotypes of Colletotrichum sublineolum in Arkansas. American Phytopathological Society, 92, 1415-1420.

[51] Garrido, C., Carbu, M., Fernandez-Acero, F. J., Budge, G., Vallego, I., Colyerand, A. and Cantoral, J.M. (2008) Isolation and Pathogenicity of Colletotrichum s Causing Anthracnose of Strawberry in South West Spain. European Journal of Plant Pathology, 120, 409-415. http://dx.doi.org/10.1007/s10658-007-9224-7

[52] Moriwaki, J., Sato, T. and Tsukiboshi, T. (2003) Morphological and Molecular Characterization of Colletotrichum boninense sp. nov. from Japan. Mycoscience, 44, 47-53. http://dx.doi.org/10.1007/S10267-002-0079-7

[53] Nguyen, P., Petersson, O.V., Olsson, P. and Liljeroth, E. (2010) Identification of Colletotrichum Species Associated with Anthracnose Diseases of Coffee in Vietnam. European Journal Plant Pathology, 127, 73-87. http://dx.doi.org/10.1007/s10658-009-9573-5

[54] Bautista-Baños, S., Hernandez-Lopez, M., Bosquez-Molina, E. and Wilson, C.L. (2003) Effects of Chitosan and Plant Extracts on Growth of Colletotrichum gloeospiodes, Anthracnose Levels and Quality of Papaya Fruit. Crop Protection, 22, 1087-1092. http://dx.doi.org/10.1016/S0261-2194(03)00117-0

[55] Montes-Belmont, R. and Carvajal, M. (1998) Control of Aspergillus flavus in Maize with Plant Essential Oils and Their Components. Journal of Food Protection, 61, 616-619. 